\title{
Thyroid cancer overdiagnosis and overtreatment: a cross- sectional study at a thyroid cancer referral center in Ecuador
}

\author{
Paola Solis-Pazmino ${ }^{1,2,3 \dagger}$, Jorge Salazar-Vega ${ }^{3,4,5+}$, Eddy Lincango-Naranjo ${ }^{2,3,6}$, Cristhian Garcia ${ }^{3,7}$, \\ Gabriela Jaramillo Koupermann ${ }^{3,8}$, Esteban Ortiz-Prado ${ }^{5^{*}}$ (D), Tannya Ledesma ${ }^{3,6}$, Tatiana Rojas ${ }^{3,9}$, \\ Benjamin Alvarado-Mafla ${ }^{3}$, Cesar Carcamo ${ }^{10}$, Oscar J. Ponce ${ }^{2,3,11}$ and Juan P. Brito 2,3,12
}

\begin{abstract}
Background: In contrast to the rapid increase in thyroid cancer incidence, the mortality has remained low and stable over the last decades. In Ecuador, however, thyroid cancer mortality has increased. The objective of this study is to determine possible drivers of high rates of thyroid cancer mortality, through a cross-sectional analysis of all patients attending a thyroid cancer referral center in Ecuador.

Methods: From June 2014 to December 2017, a cross-sectional study was conducted at the Hospital de Especialidades Eugenio Espejo, a regional reference public hospital for endocrine neoplasia in adults in Quito, Ecuador. We identified the mechanism of detection, histopathology and treatment modalities from a patient interview and review of clinical records.

Results: Among 452 patients, $74.8 \%$ were young adults and $94.2 \%$ (426) were female. 13.7\% had a family history of thyroid cancer, and patients' median tumor size was $2 \mathrm{~cm}$. The incidental finding was $54.2 \%$ whereas $45.8 \%$ was non-incidental. Thyroid cancer histology reported that 93.3\% had papillary thyroid cancer (PTC), 2.7\% follicular, 1.5\% Hurtle cells, 1.6\% medullary, $0.7 \%$ poor differentiated, and 0.2\% anaplastic carcinoma. The mean MACIS (metastasis, age, completeness, invasion, and size) score was 4.95 (Cl 4.15-5.95) with $76.2 \%$ of the thyroid cancer patients having MACIS score less than or equal to 6 . The very low and low risk of recurrence was 18.1\% (79) and 62\% (271) respectively. An analysis of 319 patients with non-metastatic thyroid cancer showed that $10.7 \%$ (34) of patients had surgical complications. Moreover, around $62.5 \%$ (80 from 128 patients with thyroglobulin laboratory results) of TC patients had a stimulated-thyroglobulin value equal or higher than $2 \mathrm{ng} / \mathrm{ml}$. Overall, a poor surgical outcome was present in 35.1\% (112) patients. Out of 436 patients with differentiated thyroid carcinoma, 86\% (375) received radioactive iodine.

Conclusion: Thyroid cancer histological characteristics and method of diagnosis are like those described in other reports without any evidence of the high frequency of aggressive thyroid cancer histology. However, we observed evidence of overtreatment and poor surgical outcomes that demand additional studies to understand their association with thyroid cancer mortality in Ecuador.
\end{abstract}

Keywords: Thyroid Cancer, Histopathology, Surgical, Outcome, Ecuador, Latin-America

\footnotetext{
* Correspondence: e.ortizprado@gmail.com

${ }^{\dagger}$ Paola Solis-Pazmino and Jorge Salazar-Vega contributed equally to this work.

${ }^{5}$ One Health Research Group, Universidad de las Americas, Quito, Ecuador,

170137 Quito, Ecuador

Full list of author information is available at the end of the article
}

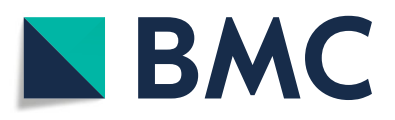

(- The Author(s). 2021 Open Access This article is licensed under a Creative Commons Attribution 4.0 International License, which permits use, sharing, adaptation, distribution and reproduction in any medium or format, as long as you give appropriate credit to the original author(s) and the source, provide a link to the Creative Commons licence, and indicate if changes were made. The images or other third party material in this article are included in the article's Creative Commons licence, unless indicated otherwise in a credit line to the material. If material is not included in the article's Creative Commons licence and your intended use is not permitted by statutory regulation or exceeds the permitted use, you will need to obtain permission directly from the copyright holder. To view a copy of this licence, visit http://creativecommons.org/licenses/by/4.0/. The Creative Commons Public Domain Dedication waiver (http://creativecommons.org/publicdomain/zero/1.0/) applies to the data made available in this article, unless otherwise stated in a credit line to the data. 


\section{Background}

The incidence of thyroid cancer (TC) has increased over the last three decades in most countries around the globe [1]. In the United States, an analysis of the Surveillance, Epidemiology, and End Results (SEER) between 1975 and 2015 found that TC incidence has increased from 4.9 to 15 per 100,000 people [2]. Similar epidemiological changes have been observed in Central and South America. From 2008 to 2012, TC rates of incidence in these regions increased 8 to 12 times [3]. In Ecuador, the annual incidence fluctuated from 3 to 22 per 100 , 000 in the last 16 years, with women having higher rates of incidence than men [4].

Thyroid cancer overdiagnosis seems to be the most important driver of thyroid cancer diagnosis, although the contribution of other risk factors (e.g., obesity) to the rise in thyroid cancer incidence is currently being investigated. In contrast with the rapid increase in TC incidence [5-8], worldwide thyroid cancer mortality has remained low and stable over the last decades [9-11]. In Ecuador, however, thyroid cancer incidence and mortality have increased, and the Ecuadorian thyroid cancer mortality rate is one of the highest in the world $[4,9$, 10]. The reason for the high thyroid cancer mortality in Ecuador is unknown.

Ideally, a large population-based study examining the thyroid cancer characteristics and treatment trends may help clarify the triggers of the rates of mortality in Ecuador. However, such a study design is not possible with the current TC data infrastructure in Ecuador. Instead, we conducted a cross-sectional analysis of all patients attending a thyroid cancer referral center in Ecuador to determine possible drivers of high rates of thyroid cancer mortality (type of thyroid cancer diagnosis and surgical outcome). This information might help gain insights into what factors could be contributing to thyroid cancer mortality.

\section{Methods}

\section{Setting and participants}

From June 2014 to December 2017, a cross-sectional study was conducted at the Hospital de Especialidades Eugenio Espejo (HEEE), a regional reference public hospital for endocrine neoplasia in adults in Quito, Ecuador. Ecuador is geographically divided into four major natural regions (Coast, Highland, Amazon, and Galapagos Islands). Due to HEEE being located within the Highland region, its patients come mostly from this area. All the patients who were seen for thyroid cancer at HEEE were included, except the patients who did not have the histopathology report. Patients who had initial management (including surgery) outside HEEE were also included.

\section{Data collection and variables}

Two sources of data were used to collect the variables of interest. First, a study coordinator interviewed eligible patients during their first postsurgical appointment at the endocrine clinic. During this process, the study coordinator captured: 1) demographic characteristics such as age, degree of education, region of residence (Coast, Highland, Amazon, or Galapagos Islands), age at diagnosis, and ethnicity; 2) family history of TC; 3) environmental risk factors; 4) methods of diagnosis (incidental or non-incidental findings). Second, study team members reviewed medical records of included patients to extract the following information: 1) thyroid gland functionality (euthyroid, hypothyroidism, or hyperthyroidism), thyroid ultrasound characteristics, and thyroid nodule fine-needle aspiration(FNA) cytologic results based on Bethesda System; 2) surgical characteristics such as type and extension of surgery; 3) thyroid gland histopathological features including tumor size, type, focality, minor or gross local invasion, and cervical lymph node involvement or distant metastases; 4) TC markers measured after thyroidectomy and before radioactive iodine therapy, including thyroid-stimulating hormone (TSH), stimulated thyroglobulin (sTg), inhibited thyroglobulin (iTg), and anti-thyroglobulin antibodies (aTg); 5) surgical characteristics such as type and extension of surgery, and complications (hypocalcemia $<6$ months and $>6$ months after procedure, recurrent laryngeal nerve injury); and finally 6) the radioactive iodine treatment, its doses, and scan results.

\section{Data management}

Baseline characteristics data were managed as follows: employment and education were classified according to the National Institute of Statistics and Census (INEC) from Ecuador [11], and thyroid surgery settings were grouped as tertiary (hospitals providing specialized TC management) and non-tertiary hospitals. Furthermore, patients were considered to have a family history of TC when first and second generation-degree relatives had the disease. Based on thyroid histopathologic features, patients were diagnosed as medullary or non-medullary $\mathrm{TC}$, the latter being further classified as differentiated (papillary and follicular), poorly differentiated, undifferentiated (anaplastic), or squamous cell carcinoma [12]. The risk of recurrence in differentiated TC was calculated by using the American Thyroid Association (ATA) 2009 risk stratification system, which classifies patients' risk of recurrence as low, intermediate, or high [13]. Due to the overwhelming increasing incidence of patients with papillary thyroid cancer (PTC) with an intrathyroidal tumor size of $<1 \mathrm{~cm}$, a new category was included to the ATA risk of recurrence calculator: "very low risk" [14]. Furthermore, the risk of mortality in patients with 
PTC was estimated based on MACIS score (metastasis, age, completeness, invasion, and size) [15]. A cutoff of 6 was employed to group patients as either low (MACIS < 6) or high risk (MACIS $\geq 6$ ) of mortality.

Thyroid cancer method of detection was divided in two groups: non-incidental diagnosis (when the TC was found in a symptomatic patient) and incidental diagnosis when a thyroid nodule harboring TC is found during the workup of non-nodular thyroid disease, or during an imaging test requested for reasons unrelated to a thyroid disorder or symptom (e.g., preventive ultrasound), or TC is found incidentally in the histological examination of the thyroid gland removed for a benign condition (Fig. 1) [16].

We classified the setting of the surgery as either tertiary hospital (HEEE and Hospital SOLCA) or nontertiary hospital. Moreover, we evaluated the quality of thyroidectomy based on post-operative sTg levels (at least 6 weeks after the procedure) [17-19], and the frequency of surgical complications [20-22]. We considered that the quality of surgery was optimal when there were no post-surgical complications and when patients had a $\mathrm{sTg} \leq 2 \mathrm{ng} / \mathrm{dl}$, and poor when patients had at least one permanent surgical complication or post-operative $\mathrm{sTg}>2 \mathrm{ng} / \mathrm{dL}$. Given that surgical complications and post-operative sTg levels could be affected by the presence of metastatic disease, we limited the assessment of the quality of surgical outcomes to patients with nonmetastatic differentiated TC undergoing initial thyroid surgery (total thyroidectomy and prophylactic central neck dissection). Before 2016, the criteria for using iodotherapy included the ATA 2009 guidelines; after 2016, the ATA 2015 guidelines were considered.

\section{Statistical methods}

For categorical variables, frequencies and percentages were reported. For numerical variables, we used mean and median with their corresponding standard deviation (SD) or interquartile ranges (IQR), as measurements of central tendency and dispersion. Normal distribution was determined by visual inspection and by using the Kolmogorov-Smirnov test. Our dependent variables used for exploratory analysis were incidental findings and quality of surgery, which are dichotomous variables. For our bivariate and multivariate analysis, we decided to use prevalence ratio (PR) instead of odds ratios (OR) because PR is easier to interpret and OR tend to overestimate the results [23]. To calculate this PR, we planned to use a generalized linear model (GLM) with the binomial family and the log link. However, convergence problems were found with some of the variables. Such issues are common [24, 25]. At the end we chose, from all possible solutions, to use Poisson as the family for the GLM with robust variance. For the multivariate analyses, we decided to include in the models for incidental findings and poor quality of surgery all variables in which $p$-value was less than 0.05 and those considered to be important by the investigators. The results are reported as PR and their respective 95\% confidence intervals. Statistical analysis was performed with STATA [26].

\section{Results}

From 2014 to 2017, 452 TC patients were included, with $74.8 \%$ of the patients between the ages of 20 and 54 years old. The median tumor size of patients was $2 \mathrm{~cm}$ [IQ 1.2, 3.1]. Around $94.2 \%$ of TC patients were female and $13.7 \%$ had a family history of TC (Table 1$)$. Thyroid cancer histology was: $93.3 \%$ had papillary thyroid cancer (PTC), 2.7\% follicular, 1.5\% Hurtle cells, 1.6\% medullary, $0.7 \%$ poor differentiated, and $0.2 \%$ anaplastic. The mean MACIS score was 4.95 (IQ 4.15, 5.95) with $76.2 \%$ of the TCs having MACIS score equal or less than 6 (Table 2).

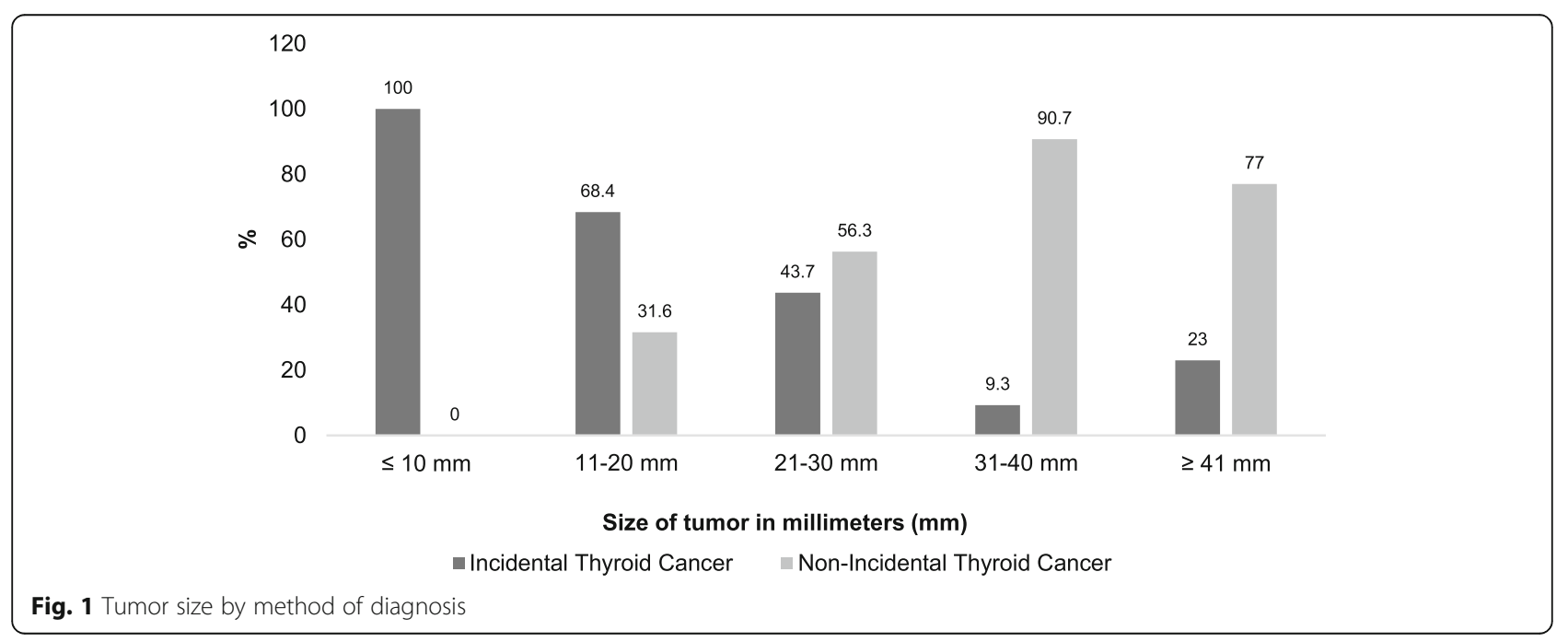




\section{Mechanism of detection}

The methods of TC diagnosis were: $54.2 \%$ incidental (93.5\% by ultrasound, $5.3 \%$ histology, and $1.2 \%$ unrelated test) and $45.8 \%$ non-incidental (palpable and symptomatic nodule) (Fig. 1). Furthermore, $100 \%$ of patients with microcarcinoma $(\leq 10 \mathrm{~mm})$ were incidental finding; the proportions further fell to 68.4, 43.7, 9.3, and $23 \%$ for the $11-20 \mathrm{~mm}, \quad 21-30 \mathrm{~mm}, \quad 31-40 \mathrm{~mm}$ and $\geq 41 \mathrm{~mm}$ groups, respectively (Fig. 2). The univariate analysis showed that age, tumor size, and MACIS score were associated with the mechanism of detection (Table 3).

\section{Treatment modalities}

\section{Surgical characteristics and outcomes}

All patients were treated with total thyroidectomy. The operations were performed by the HEEE surgery team (7 surgeons) in 46\% (205) of patients. Other patients had operations in other institutions and were transferred to the HEEE to continue the follow-up. The neck dissection was performed as follows: 46\% (209) central compartment, 22\% (97) lateral compartment, and 32\% (146) did not have neck dissection. Of patients with central compartment neck dissection, 16\% (34) had more than 5 positive lymph nodes removed. An analysis of 319 patients with non-metastatic differentiated thyroid carcinoma (DTC) showed that $10.7 \%$ (34) of patients had surgical complications, $7.8 \%$ (25) of patients developed permanent hypoparathyroidism, $2.2 \%$ (7) had recurrent laryngeal nerve injury, and $0.6 \%$ (2) showed spinal nerve injury. Moreover, around 61\% (80 from 128 patients with thyroglobulin laboratory results) of TC patients had a sTg value equal or higher than $2 \mathrm{ng} / \mathrm{ml}$. By using both surgical complications and sTg values, the percentage of patients who had a poor surgical outcome was $35 \%$. The univariate analysis showed that the tumor size, MACIS score and the presence of metastatic cervical lymph nodes in the central compartment were associated with poor surgical outcome. However, in multivariate analysis, only metastatic cervical lymph nodes were associated with poor surgical outcome $(\mathrm{PR}=1.45$ [IC:1.07, 1.97]) (Table 4).

\section{lodine therapy}

Out of 436 patients with DTC, 86\% (375) received RAI. The median dose of RAI was $100 \mathrm{mCi}$ (IQR: 100-150) and the median lapse between surgery and RAI therapy was 4 months (IQR: $3-7$ months). $95 \%$ of people with very low risk and low risk received RAI treatment (Table 5).

\section{Discussion}

We conducted a cross-sectional analysis of all TC patients receiving care at a regional reference hospital in Ecuador. This analysis revealed that $74.8 \%$ of TC patients were between 20 and 54 years old, and the majority was papillary thyroid cancer at low or very low risk of recurrence. Approximately half of these cases were found incidentally, and a quarter of TC patients had a poor surgical outcome. Despite being mostly low risk for cancer, all patients received total thyroidectomy, and the majority received RAI.

Although this sample only represents a small subset of all thyroid cancers in Ecuador, histological characteristics and methods of diagnosis are similar to the ones described in other reports [27-31]. We did not see an increased frequency of aggressive thyroid cancer histological findings that might explain the increase in thyroid cancer mortality in Ecuador. We observed that the majority of thyroid cancer cases were of low risk of recurrence and mortality. Moreover, we found that more than half of thyroid cancers were diagnosed incidentally, and the minority of patients presented with symptoms resembling findings in countries where thyroid cancer overdiagnosis drives increasing incident trends [32-35]. The driver of incidental thyroid cancer in this cohort was the used of neck ultrasound. This finding is consistent with other studies that shows that the use of thyroid ultrasound has increased at a rate of $20 \%$ per year from 2002 through 2013 in the United States [36, 37] and was associated with more thyroid cancer diagnosis, this cancer found by neck ultrasound was mostly of low risk. Although thyroid cancer histology and mode of presentation did not show any hint to explain thyroid cancer increased mortality, we found that there was evidence of overtreatment and poor surgical outcomes. One-third of patients had either surgical adverse events or a post-surgical Tg value that suggested residual benign or malignant thyroid tissue. Persistent thyroglobulin in our cohort may be the result of both insufficient surgical treatment of cervical lymph node metastases and a significant remnant of thyroid tissue in the glandular bed. The high frequencies of poor surgical outcomes suggest a lack of surgical thyroid cancer expertise [38-40]. In Ecuador, there are no residency programs dedicated to training surgeons about the treatment of TC. The few existing thyroid focused surgeons are insufficient in covering the rising demand for new patients with this tumor; therefore, before 2017 most of our patients underwent a thyroidectomy with a general surgeon and most of the patients underwent prophylactic central or lateral neck dissection (68\%). In light of this, a retrospective study assessed the safety and efficiency of thyroid surgery, it found more hypocalcemia <2.0 $\mathrm{mmol} / \mathrm{l}$ (32.8 vs. $22.0 \%)$ and postoperative hemorrhage $(5.6 \%$ vs. $1.9 \%)$ in surgeries performed by general surgeons [40]. These poor surgical outcomes might be higher among countries affected by higher rates of TC diagnosis that have limited thyroid surgical expertise 
Table 1 Characteristics of Thyroid Cancer Patients Before Thyroidectomy

\begin{tabular}{llc}
\hline Variable $^{\mathbf{a}}$ & Total $(\boldsymbol{n}=\mathbf{4 5 2})$ & $\mathbf{n}(\%)$ \\
\hline Sex & & \\
Female & 426 & 94.2 \\
Males & 26 & 5.8
\end{tabular}

Age at diagnosis (mean: 44.6, SD: 14.56)

$$
\begin{aligned}
& <20 \text { years old } \\
& \text { 20-34 years old } \\
& \text { 35-44 years old } \\
& 45-54 \text { years old } \\
& \text { 55-64 years old } \\
& \text { 65-74 years old } \\
& 75-84 \text { years old } \\
& >84 \text { years old }
\end{aligned}
$$

Residence

$$
\begin{aligned}
& \text { Coast } \\
& \text { Highland } \\
& \text { Amazon } \\
& \text { Galapagos }
\end{aligned}
$$

Employment

Domestic chores
Student
Labor

Education level

$$
\text { None }
$$

Elementary School

High school

$$
\text { College }
$$

Family history of thyroid cancer

$$
\text { Yes }
$$$$
\text { No }
$$

BMI $(n=298)$ (mean: 28.75, SD: 5.53)

Normal

Obesity

Self-reported exposure to $(n=63)$

Radiation

Chemicals in agriculture

Cigarette Smoking ( $n=393)$

$$
\text { Yes }
$$

No

Thyroid function

$$
\text { Euthyroid }
$$

Hypothyroidism

Hyperthyroidism

\begin{tabular}{|c|c|c|}
\hline \multirow{2}{*}{$\frac{\text { Variable }^{\mathrm{a}}}{\text { Methods of detection }}$} & \multicolumn{2}{|c|}{ Total $(n=452) n(\%)$} \\
\hline & & \\
\hline Non-incidental (palpable nodule) & 207 & 45.8 \\
\hline Incidental & 245 & 54.2 \\
\hline - Ultrasound & 229 & 93.5 \\
\hline - Histology & 13 & 5.3 \\
\hline - Unrelated test & 3 & 1.2 \\
\hline \multicolumn{3}{|l|}{ Setting of thyroid surgery $(n=450)$} \\
\hline Tertiary Hospital & 270 & 60 \\
\hline Non- tertiary hospital & 180 & 40 \\
\hline \multicolumn{3}{|c|}{ Size of tumor $(n=406)($ median $=2 \mathrm{~cm}[I Q 1.2,3.1])$} \\
\hline$\leq 1 \mathrm{~cm}$ & 89 & 21.9 \\
\hline$>1 \mathrm{~cm}$ & 317 & 78.1 \\
\hline \multicolumn{3}{|l|}{ Focality $(n=416)$} \\
\hline Unifocal & 230 & 55.3 \\
\hline Multifocal & 186 & 44.7 \\
\hline \multicolumn{3}{|c|}{ Cervical Lymph nodes metastasis ( $n=436$ ) } \\
\hline $\mathrm{Si}$ & 211 & 48.4 \\
\hline No & 225 & 51.6 \\
\hline \multicolumn{3}{|c|}{ MACIS score $(n=408)($ median $=4.95 \mathrm{~cm}[I Q 4.15,5.95])$} \\
\hline$\leq 6$ & 311 & 76.2 \\
\hline$>6$ & 97 & 23.8 \\
\hline \multicolumn{3}{|l|}{ Histopathology, $(n=447)$} \\
\hline Papillary & 417 & 93.3 \\
\hline Follicular & 12 & 2.7 \\
\hline Hurtle cells & 7 & 1.5 \\
\hline Poor differentiated & 3 & 0.7 \\
\hline Anaplastic & 1 & 0.2 \\
\hline Medullary & 7 & 1.6 \\
\hline \multicolumn{3}{|l|}{ Risk recurrence $(n=437)$} \\
\hline Very low risk & 79 & 18.1 \\
\hline Low risk & 271 & 62.0 \\
\hline Indeterminate risk & 49 & 11.2 \\
\hline High risk & 38 & 8.7 \\
\hline
\end{tabular}

Table 1 Characteristics of Thyroid Cancer Patients Before Thyroidectomy (Continued)

${ }^{a}$ All variables without a specific number of patients were calculated from the whole population $(n=452)$. All the others show the number of people from which the variables were available

[21] (e.g., Ecuador). Yet, most TC patients do not receive care or treatment in a reference hospital, and thus, they may be at higher risk of complications (e.g., hypocalcemia, recurrent laryngeal nerve injury, etc.) and perhaps unrecognized death due to thyroid cancer surgery.

Another driver of the increased thyroid cancer mortality in Ecuador, not assessed in this study, may be attribution bias. That is, patients with thyroid cancer who died, and the cause 
Table 2 Factors associated with the prevalence of diagnosis

\begin{tabular}{|c|c|c|c|c|c|c|}
\hline \multirow{3}{*}{ Variables } & \multicolumn{2}{|l|}{ Incidental } & \multicolumn{2}{|c|}{ Univariate analysis } & \multirow[t]{3}{*}{ Multivariate analysis } & \\
\hline & \multirow{2}{*}{$\begin{array}{l}\text { No } \\
n=206\end{array}$} & \multirow{2}{*}{$\begin{array}{l}\text { Yes } \\
n=246\end{array}$} & \multirow[t]{2}{*}{ PR $(95 \% \mathrm{Cl})$} & \multirow[t]{2}{*}{$p$} & & \\
\hline & & & & & & \\
\hline Age, mean (SD) & $43.0(16.1)$ & $46.3(13.4)$ & $1.01(1.00,1.01)$ & 0.037 & $1.01(1.00,1.02)$ & 0.033 \\
\hline \multicolumn{7}{|l|}{ Sex, n (\%) } \\
\hline Male & $14(6.8)$ & $12(4.9)$ & Reference & \multirow[t]{2}{*}{0.433} & & \\
\hline Female & $192(93.2)$ & $234(95.1)$ & $1.19(0.78,1.81)$ & & & \\
\hline \multicolumn{7}{|l|}{ Positive Family history n (\%) } \\
\hline No & $179(86.5)$ & $211(86.1)$ & Reference & \multirow[t]{2}{*}{0.914} & & \\
\hline Yes & 28 (13.6) & $34(13.8)$ & $1.01(0.79,1.29)$ & & & \\
\hline BMI, $(n=299)$ mean, (SD) & $\begin{array}{l}n=142 \\
28.6(5.7)\end{array}$ & $\begin{array}{l}n=157 \\
29.2(5.8)\end{array}$ & $1.00(0.99,1.02)$ & 0.630 & & \\
\hline Tumor size in $\mathrm{mm},(n=406)$ mean, $(\mathrm{SD})$ & $\begin{array}{l}n=177 \\
35.7(17.9)\end{array}$ & $\begin{array}{l}n=229 \\
22.3(12.3)\end{array}$ & $0.96(0.95,0.97)$ & 0.000 & $0.96(0.94,0.97)$ & 0.000 \\
\hline \multicolumn{7}{|l|}{ Multifocal $(n=328), \mathrm{n}(\%)$} \\
\hline Unifocal, n (\%) & $103(55.4)$ & $127(55.2)$ & Reference & \multirow[t]{2}{*}{0.974} & Reference & \multirow[t]{2}{*}{0.000} \\
\hline Multifocal, n (\%) & $83(44.6)$ & $103(44.8)$ & $1.00(0.84,1.19)$ & & $1.32(1.13,1.54)$ & \\
\hline \multicolumn{7}{|l|}{ Positive Cervical Lymph nodes, n (\%) } \\
\hline No & $93(46.3)$ & $132(56.2)$ & Reference & \multirow[t]{2}{*}{0.041} & Reference & \multirow[t]{2}{*}{0.305} \\
\hline Yes & $108(53.7)$ & $103(43.8)$ & $0.83(0.70,0.99)$ & & $1.09(0.93,1.27)$ & \\
\hline MACIS score $(n=406)$, mean (SD) & $5.6(1.6)$ & $4.9(1.4)$ & $0.86(0.79,0.92)$ & 0.000 & $0.92(0.81,1.04)$ & 0.184 \\
\hline \multicolumn{7}{|l|}{ Risk recurrence $(n=437)$} \\
\hline Very low risk & 0 & $79(33)$ & Reference $^{a}$ & & & \\
\hline Low risk & $147(73.5)$ & $124(52.3)$ & & & & \\
\hline Intermediate risk & $33(16.5)$ & $16(6.8)$ & $0.56(0.37,0.85)$ & 0.006 & $0.98(0.67,1.43)$ & 0.902 \\
\hline High risk & $20(10.0)$ & $18(7.6)$ & $0.77(0.54,1.11)$ & 0.163 & $1.04(0.82,2.16)$ & 0.239 \\
\hline
\end{tabular}

${ }^{\mathrm{a}}$ For univariate and multivariate analysis low and very low risk categories were combined and taken as reference

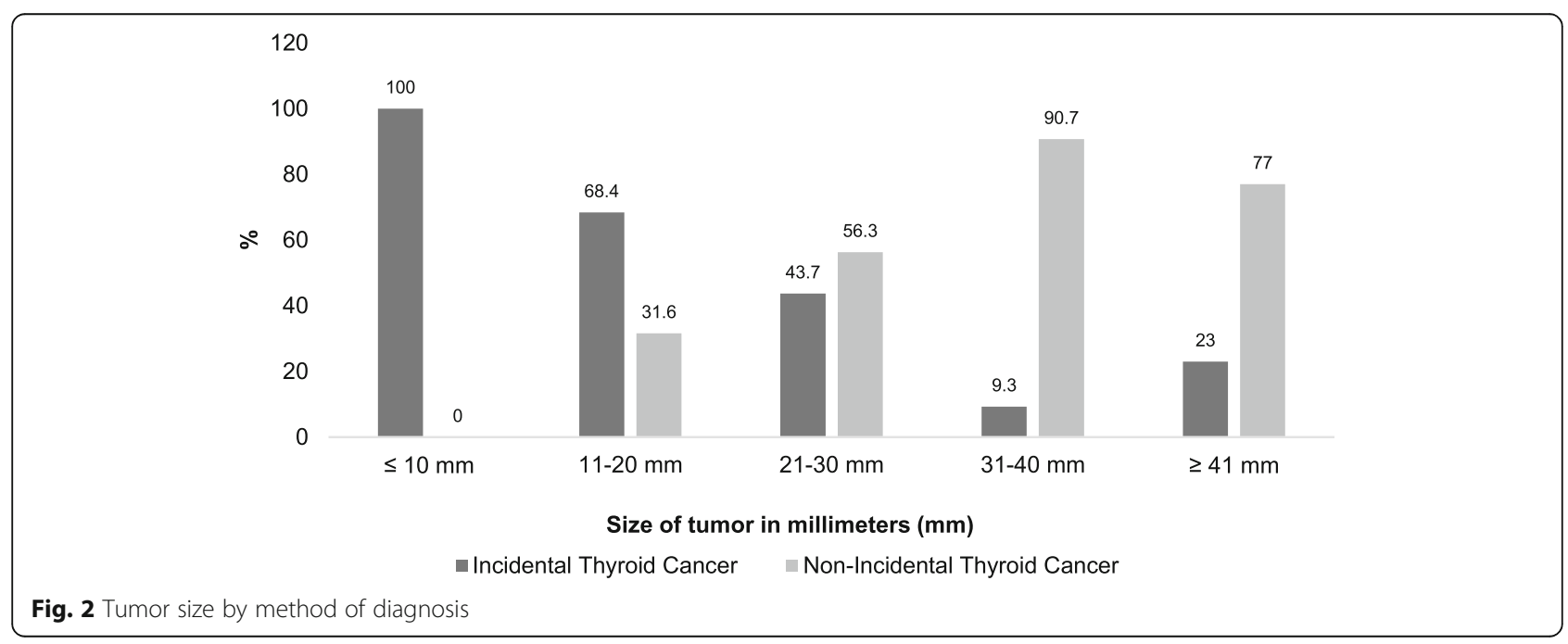


Table 3 Factors associated with poor optimal surgical outcomes

\begin{tabular}{|c|c|c|c|c|}
\hline & \multicolumn{2}{|c|}{ Univariate analysis } & \multirow{2}{*}{$\begin{array}{l}\text { Multivariate analysis } \\
\text { PR }(95 \% \mathrm{Cl})\end{array}$} & \multirow[b]{2}{*}{$P$ value } \\
\hline & PR $(95 \% \mathrm{Cl})$ & $P$ value & & \\
\hline \multicolumn{5}{|l|}{ Sex } \\
\hline Male & Reference & 0.295 & & \\
\hline Female & $0.74(0.42,1.30)$ & & & \\
\hline Age, mean (SD) & $1.00(0.99,1.01)$ & 0.684 & & \\
\hline BMI & $1.02(0.99,1.05)$ & 0.191 & & \\
\hline \multicolumn{5}{|l|}{ Setting of Surgery } \\
\hline - Tertiary Hospital & Reference & 0.878 & Reference & 0.947 \\
\hline - Non- tertiaty hospital & $0.98(0.71,1.32)$ & & $1.01(0.75,1.37)$ & \\
\hline Tumor size $(n=306)$, mean (SD) & $1.01(1.00,1.02)$ & 0.001 & $1.01(1.00,1.02)$ & 0.182 \\
\hline \multicolumn{5}{|l|}{ Tumor focality, n (\%) } \\
\hline - Unifocal & Reference & 0.425 & & \\
\hline - Multifocal & $1.13(0.84,1.53)$ & & & \\
\hline \multicolumn{5}{|c|}{ Positive Central Cervical Lymph nodes metastasis, n (\%) } \\
\hline - No & Reference & 0.004 & Reference & 0.017 \\
\hline - Yes & $1.54(1.15,2.06)$ & & $1.45(1.07,1.97)$ & \\
\hline MACIS score & $1.14(1.02,1.28)$ & 0.017 & $1.08(0.94,1.24)$ & 0.285 \\
\hline \multicolumn{5}{|l|}{ Histology variant } \\
\hline - Non- aggresive & Reference & 0.651 & & \\
\hline - Aggresive & $1.11(0.70,1.79)$ & & & \\
\hline \multicolumn{5}{|l|}{ Risk recurrence } \\
\hline Very low risk & Reference $^{a}$ & & & \\
\hline \multicolumn{5}{|l|}{ Low risk } \\
\hline Indeterminate risk & $0.95(0.51,1.77)$ & 0.861 & & \\
\hline High risk & $0.95(0.19,4.73)$ & 0.946 & & \\
\hline
\end{tabular}

${ }^{a}$ For univariate and multivariate analysis low and very low risk categories were combined and taken as reference

of death is attributed to thyroid cancer even if cancer was likely not the cause of death [41]. This misclassification bias exaggerates cancer-specific mortality. Morticians not familiar with thyroid cancer prognosis may be more willing to allocate cause of death to thyroid cancer when the chain of events leading to death is unclear or unknown. Moreover, we observed that the majority of thyroid cancer cases were of low or very low risk of recurrence, however, most of them received high doses of RAI therapy. In our study, it is not clear if the rise observed in the use of RAI is associated with diagnosis of higher-risk tumors or if clinicians continue to prescribe RAI due to a lack of knowledge or for thyroid remnant ablation. Although RAI use would not have a detrimental impact on thyroid cancer mortality, its use adds to the patient's burden of treatment and risk of adverse events [42-44].

\section{Limitations and strengths}

This study has several limitations. This is not a populationbased study; therefore, selection bias may influence our results. Furthermore, there were patients with missing data,

Table 4 Radioactive lodine and risk of recurrence

\begin{tabular}{|c|c|c|c|c|}
\hline Risk recurrence & Yes $n=375(89.3 \%)$ & No $n=45(10.7 \%)$ & PR $(95 \% \mathrm{Cl})$ & $P$ value \\
\hline Very low risk (micro PTC) n (\%) & 49 (63.6) & $28(36.4)$ & $0.2(0.13,0.35)$ & 0.001 \\
\hline Low risk & $248(95)$ & $13(5)$ & & \\
\hline Indeterminate risk & $43(91.5)$ & $4(8.5)$ & & \\
\hline High risk & 35 (100) & $0(0)$ & & \\
\hline
\end{tabular}


Table 5 Radioactive lodine Treatment in patients with thyroid cancer by their risk of recurrence

\begin{tabular}{|c|c|c|c|c|}
\hline \multirow[t]{3}{*}{ Variables } & \multicolumn{4}{|c|}{ Radioactive lodine Treatment } \\
\hline & Yes & No & PR $(95 \% \mathrm{Cl})$ & $p$ value \\
\hline & $n=375(89.3 \%)$ & $n=45(10.7 \%)$ & & \\
\hline \multicolumn{5}{|l|}{ Risk of recurrence } \\
\hline - Very low risk (micro PTC) n (\%) & 49 (63.6) & $28(36.4)$ & $0.2(0.13,0.35)$ & 0.001 \\
\hline - Low risk & $248(95)$ & $13(5)$ & & \\
\hline - Indeterminate risk & $43(91.5)$ & $4(8.5)$ & & \\
\hline - High risk & $35(100)$ & $0(0)$ & & \\
\hline
\end{tabular}

lowering our sample size and confidence in the estimates. Information about the histopathological characteristics and post-surgical treatment were unavailable because not all patients began the treatment in HEEE and some of them came to this hospital after surgery or after radioactive therapy was performed. Moreover, in the interview of the patients, the question of family history was exposed to recall bias. Finally, we were not able to provide information about the outcomes for these patients as this data is currently being collected as data for a subsequent study. Despite these limitations, this study has several strengths. First, patient data was collected by extractors trained in thyroid cancer treatment and diagnosis using a well-designed extraction form. Second, our inclusion criteria and case finding process secured that all patients treated at the hospital were include for analysis. Finally, our team included a multidisplinary team of clinicians, thyroid cancer researched and epidemiologists who contributed to planning, execution, and dissemination of study's results.

\section{Conclusion}

Considering the paucity of population-based cancer registries in Ecuador, this study provides additional information about the thyroid cancer diagnosis and treatment in a tertiary referral center in Ecuador. We observed that thyroid cancer histological characteristics and methods of diagnosis are like those described in other reports without any evidence of the high frequency of aggressive thyroid cancer histology. However, we observed evidence of overtreatment and poor surgical outcomes that demand additional studies to understand their association with thyroid cancer mortality in Ecuador. This study is significant because it shows the high rate of overtreatment for patients seen in a tertiary care center for thyroid cancer in Ecuador, particularly the high frequency of surgical adverse outcomes among patients with low-risk thyroid cancer, who may benefit from non-surgical options for their management. These results further invite to better understand the potential association of overtreatment and thyroid cancer mortality.

\section{Abbreviations \\ TC: Thyroid Cancer; HEEE: Hospital de Especialidades Eugenio Espejo; MACl S: Metastasis, age, completeness, invasion, and size; DTC: Differentiated thyroid carcinoma; RAI: Radioactive iodine; SEER: Surveillance, Epidemiology, and End Results; FNA: Fine-needle aspiration; TSH: Thyroid-stimulating hormone; sTg: Stimulated thyroglobulin; iTg : Inhibited thyroglobulin; aTg: Anti-thyroglobulin antibodies; INEC: National Institute of Statistics and Census; ATA: American Thyroid Association; PTC: Papillary thyroid cancer; SD: Standard deviation; IQR: Interquartile ranges; PR: Prevalence ratio; OR: Odds ratios; GLM: Generalized linear model}

\section{Acknowledgements}

The authors thank the patients and their families who contributed to the completion of this analysis.

\section{Authors' contributions}

PSP and JLS were fully responsible for the conceptualization, data collection and elaboration of the study and both participated in drafting the manuscript equally and are fully responsible for it. EL, GJ and CG contributed with the data collection (surgical information and pathological analysis) and the construction of figures and Tables. TL, TR, BA, CC, and OP contributed with the descriptive statistical analysis and the discussion section of the manuscript. EO-P and JPB added an important insight about the epidemiological point of view regarding rates of mortality and the overall analysis of thyroid cancer in Ecuador, respectively. Both critically reviewed the entire manuscript and produced several comments prior to the submission. All authors have read and approved the manuscript.

\section{Funding}

This work: design of the study and collection, analysis, interpretation of data, and writing, did not receive financial support of any kind except for the publication fee paid in full by Universidad de las Americas, Quito, Ecuador.

\section{Availability of data and materials}

Since data came from the medical records where sensitive information is collected, no database is publicly available. Nevertheless, anonymized information can be shared privately upon reasonable request at e.ortizprado@gmail.com or paosolis@stanford. edu.

\section{Ethics approval and consent to participate}

All data were collected from the patient's medical records after obtaining written informed consent. The study was approved by the Hospital Eugenio Espejo review board. All data was anonymized, and all identifiable information and biological samples were stored according to the local guidelines.

\section{Consent for publication}

Written informed consent was obtained from every patient in the study.

\section{Competing interests}

The authors declare that they have no competing interests. 


\section{Author details}

Otolaryngology Head and Neck Department, Stanford University, Palo Alto, California, USA. ${ }^{2}$ Knowledge and Evaluation Research Unit, Mayo Clinic, Rochester, MN, USA. ${ }^{3}$ CaTaLiNa (Thyroid Cancer in LatinAmerica), Quito, Ecuador. ${ }^{4}$ Endocrinology Department, Hospital de Especialidades Eugenio Espejo, Quito, Ecuador. ${ }^{5}$ One Health Research Group, Universidad de las Americas, Quito, Ecuador, 170137 Quito, Ecuador. ${ }^{6}$ Universidad Central del Ecuador, Medical School, Quito, Ecuador. ${ }^{7}$ Surgery Department, Hospital de Especialidades Eugenio Espejo, Quito, Ecuador. ${ }^{8}$ Molecular Biology Department, Hospital de Especialidades Eugenio Espejo, Quito, Ecuador. ${ }^{9}$ Universidad San Francisco de Quito, Quito, Ecuador. ${ }^{10}$ School of Public Health and Administration, Universidad Peruana Cayetano Heredia, Lima, Peru. ${ }^{11}$ Unidad de Conocimiento y Evidencia, Universidad Peruana Cayetano Heredia, Lima, Peru. ${ }^{12}$ Division of Endocrinology, Diabetes, Metabolism, and Nutrition, Mayo Clinic, Rochester, MN, USA.

\section{Received: 16 October 2019 Accepted: 15 December 2020}

Published online: 08 January 2021

\section{References}

1. Wiltshire JJ, Drake TM, Uttley L, Balasubramanian SP. Systematic review of trends in the incidence rates of thyroid Cancer. Thyroid. 2016;26:1541-52. https://doi.org/10.1089/thy.2016.0100.

2. Howlader N, Noone AM, Krapcho M, Miller D, Bishop K, Kosary CL, Yu M, Ruhl J, Tatalovich Z, Mariotto A, Lewis DR, Chen HS, Feuer EJCK. SEER Cancer Statistics Review 1975-2014 National Cancer Institute SEER Cancer Statistics Review 1975-2014 National Cancer Institute; 2017. p. 2012-4.

3. Sierra MS, Soerjomataram I, Forman D. Thyroid cancer burden in central and South America. Cancer Epidemiol. 2016;44:S150-7. https://doi.org/10.1016/j. canep.2016.07.017.

4. Salazar-Vega J, Ortiz-Prado E, Solis-Pazmino P, Gómez-Barreno L, SimbañaRivera K, Henriquez-Trujillo AR, et al. Thyroid Cancer in Ecuador, a 16 years population-based analysis (2001-2016). BMC Cancer. 2019;19:294. https:// doi.org/10.1186/s12885-019-5485-8.

5. Lim H, Devesa SS, Sosa JA, Check D, Kitahara CM. Trends in thyroid Cancer incidence and mortality in the United States, 1974-2013. Jama. 2017;317: 1338. https://doi.org/10.1001/jama.2017.2719.

6. Minelli G, Conti S, Manno V, Olivieri A, Ascoli V. The geographical pattern of thyroid Cancer mortality between 1980 and 2009 in Italy. Thyroid. 2013;23: 1609-18. https://doi.org/10.1089/thy.2013.0088.

7. Keinan-Boker L, Silverman BG. Trends of thyroid Cancer in Israel: 1980-2012. Rambam Maimonides Med J. 2016;7:e0001. https://doi.org/10.5041/RMMJ. 10228.

8. Rosário PW, Ward LS, Carvalho GA, Graf H, Maciel RMB, Maciel LMZ, et al. Thyroid nodules and differentiated thyroid cancer: update on the Brazilian consensus. Arq Bras Endocrinol Metabol. 2013;57:240-64. https://doi.org/10. 1590/S0004-27302013000400002.

9. La Vecchia C, Malvezzi M, Bosetti C, Garavello W, Bertuccio P, Levi F, et al. Thyroid cancer mortality and incidence: a global overview. Int J Cancer. 2015:136:2187-95

10. Enrique López G, Kempis Guerrero F, Segale Bajaña A, et al. Trends of Thyroid Cancer Mortality Rates in Ecuador. J Endocrinol Diab. 2018;5(5):1-6. https://doi.org/10.15226/2374-6890/5/5/001114.

11. INEC. Anuario de Estadisticas vitales: Nacimientos y Defunciones. 2013.

12. King-yin LA. Pathology of endocrine tumors update: World Health Organization new classification 2017-other thyroid tumors. AJSP Rev Reports. 2017;22:209-16.

13. Haugen BR. 2015 American Thyroid Association management guidelines for adult patients with thyroid nodules and differentiated thyroid Cancer: what is new and what has changed? Cancer. 2017;123:372-81. https://doi.org/10. 1002/cncr.30360

14. Pitoia F, Califano I, Vázquez A, Faure E, Gauna A, Orlandi A, et al. Consenso intersocietario* sobre tratamiento y seguimiento de pacientes con cáncer diferenciado de tiroides. Rev Argent Endocrinol Metab. 2014;51:85-118

15. Tuttle RM, Haugen B, Perrier ND. Updated American joint committee on Cancer/tumor-node-metastasis staging system for differentiated and anaplastic thyroid Cancer (eighth edition): what changed and why? Thyroid. 2017;27:751-6. https://doi.org/10.1089/thy.2017.0102.

16. Brito JP, AI Nofal A, Montori VM, Hay ID, Morris JC. The impact of subclinical disease and mechanism of detection on the rise in thyroid Cancer incidence: a population-based study in Olmsted County, Minnesota during 1935 through 2012. Thyroid. 2015;25:999-1007. https://doi.org/10.1089/thy. 2014.0594.

17. Lee Jl, Chung YJ, Cho BY, Chong S, Seok JW, Park SJ. Postoperativestimulated serum thyroglobulin measured at the time of ${ }^{131} \mathrm{I}$ ablation is useful for the prediction of disease status in patients with differentiated thyroid carcinoma. Surg (United States). 2013;153:828-35. https://doi.org/10. 1016/j.surg.2012.12.008.

18. Chang YW, Kim HS, Jung SP, Kim HY, Lee JB, Bae JW, et al. Pre-ablation stimulated thyroglobulin is a better predictor of recurrence in pathological N1a papillary thyroid carcinoma than the lymph node ratio. Int J Clin Oncol. 2016;21:862-8.

19. Salvatori M, Raffaelli M, Castaldi P, Treglia G, Rufini V, Perotti G, et al. Evaluation of the surgical completeness after total thyroidectomy for differentiated thyroid carcinoma. Eur J Surg Oncol. 2007;33:648-54 http:// ovidsp.ovid.com/ovidweb.cgi?T=JS\&CSC $=$ Y\&NEWS=N\&PAGE=fulltext\&D= med5\&AN=17433606 http://sfxhosted.exlibrisgroup.com/mayo?sid=OVID: medline\&id=pmid:17433606\&id=doi:10.1016\%2Fj.ejso.2007.02.034\&issn=074 8-7983\&isbn $=\&$ volume $=33 \&$ issue $=5 \&$ spage $=648 \&$ pages $=648$ -

20. Papaleontiou M, Hughes DT, Guo C, Banerjee M, Haymart MR. Populationbased assessment of complications following surgery for thyroid cancer. J Clin Endocrinol Metab. 2017;102:2543-51.

21. Adam MA, Thomas S, Youngwirth L, Hyslop T, Reed SD, Scheri RP, et al. Is there a minimum number of thyroidectomies a surgeon should perform to optimize patient outcomes? Ann Surg. 2017;265:402-7.

22. Liu JB, Sosa JA, Grogan RH, Liu Y, Cohen ME, Ko CY, et al. Variation of thyroidectomy-specific outcomes among hospitals and their association with risk adjustment and hospital performance. JAMA Surg. 2018;153:1-10.

23. Barros AJD, Hirakata VN. Alternatives for logistic regression in cross-sectional studies: an empirical comparison of models that directly estimate the prevalence ratio. BMC Med Res Methodol. 2003;3:1-13.

24. Espelt A, Marí-Dell M, Penelo E, Bosque-Prous M. Resumen Abstract Applied Prevalence Ratio estimation with different Regression models: An example from a cross-national study on substance use research Estimación de la Razón de Prevalencia con distintos modelos de Regresión: Ejemplo de un estudio interna. Adicciones. 2016;29:105-12 https://pdfs.semanticscholar. org/6325/45c807ee22974ee92aa74f5287159104a543.pdf.

25. Coutinho LMS, Scazufca M, Menezes PR. Methods for estimating prevalence ratios in cross-sectional studies. Rev Saude Publica. 2008;42:992-8 http:// www.ncbi.nlm.nih.gov/pubmed/19009156.

26. Stata: Software for Statistics and Data Science. https://www.stata.com/. Accessed 9 Dec 2020.

27. Weeks KS, Kahl AR, Lynch CF, Charlton ME. Racial/ethnic differences in thyroid cancer incidence in the United States, 2007-2014. Cancer. 2018: 2007-14. https://doi.org/10.1002/cncr.31229.

28. Russo Picasso MF, Vicens J, Giuliani C, Jaén ADV, Cabezón C, Figari M, et al. Role of the mechanisms of detection in the increased risk of thyroid Cancer: a retrospective cohort study in an $\mathrm{HMO}$ in Buenos Aires. J Cancer Epidemiol. 2018;2018.

29. Tsuda T, Tokinobu A, Yamamoto E, Suzuki E. Thyroid Cancer detection by ultrasound among residents ages 18 years and younger in Fukushima. Japan Epidemiology. 2016;27:316-22. https://doi.org/10.1097/EDE. 0000000000000385

30. AL-A Y, AL-M B, AL-R O, Tunio MA, Islam T, AL-A M, et al. Impact of body mass index on survival outcome in patients with differentiated thyroid cancer. Brazilian J Otorhinolaryngol. 2017:25 http://ovidsp.ovid.com/ ovidweb.cgi?T=JS\&CSC=Y\&NEWS=N\&PAGE=fulltext\&D=cctr\&AN=CN-01371 740 http://sfxhosted.exlibrisgroup.com/mayo?sid=OVID:cctrdb\&id=pmid:10.1 016\%2Fj.bjorl.2017.02.002\&id=doi:\&issn=\&isbn=\&volume=Date+of+ Publication\%3A+June $+25 \&$ issue $=\&$ spage $=\&$.

31. Estrada-Florez AP, Bohórquez ME, Sahasrabudhe R, Prieto R, Lott P, Duque CS, et al. Clinical features of Hispanic thyroid cancer cases and the role of known genetic variants on disease risk. Med (United States). 2016;95:1-7. https://doi.org/10.1097/MD.0000000000004148.

32. Janovsky CCPS, Bittencourt MS, Novais MAP d, Maciel RMB, Biscolla RPM. Thyroid cancer burden and economic impact on the Brazilian public health system. Arch Endocrinol Metab. 2018;62:537-44. https://doi.org/10.20945/ 2359-3997000000074.

33. Massimino M, Evans DB, Podda M, Spinelli C, Collini P, Pizzi N, et al. Thyroid cancer in adolescents and young adults. Pediatr Blood Cancer. 2018;65(8). https://doi.org/10.1002/pbc.27025. 
34. Seib CD, Sosa JA. Evolving understanding of the epidemiology of thyroid Cancer. Endocrinol Metab Clin N Am. 2019;48:23-35. https://doi.org/10. 1016/j.ecl.2018.10.002.

35. Brito JP, Davies L. Is there really an increased incidence of thyroid cancer? Curr Opin Endocrinol Diabetes Obes. 2014;21:405-8. https://doi.org/10.1097/ MED.0000000000000094.

36. Li M, Maso LD, Vaccarella S. Global trends in thyroid cancer incidence and the impact of overdiagnosis. Lancet Diabetes Endocrinol. 2020;8:468-70.

37. Haymart MR, Banerjee M, Reyes-Gastelum D, Caoili E, Norton EC. Thyroid ultrasound and the increase in diagnosis of low-risk thyroid Cancer. J Clin Endocrinol Metab. 2018;104:785-92.

38. Cavalheiro BG, Matos LL, Leite AKN, Kulcsar MAV, Cernea CR, Brandão LG. Surgical treatment for thyroid carcinoma: retrospective study with 811 patients in a Brazilian tertiary hospital. Arch Endocrinol Metab. 2016;60:4728. https://doi.org/10.1590/2359-3997000000209.

39. Doubleday A, Sippel RS. Surgical options for thyroid cancer and postsurgical management. Expert Rev Endocrinol Metab. 2018;13:137-48. https://doi.org/10.1080/17446651.2018.1464910.

40. Kohnen B, Schürmeyer C, Schürmeyer TH, Kress P. Surgery of benign thyroid disease by ENT/head and neck surgeons and general surgeons: 233 cases of vocal fold paralysis in 3509 patients. Eur Arch Oto-Rhino-Laryngology. 2018; 275:2397-402. https://doi.org/10.1007/s00405-018-5077-2.

41. Leite AKN, Cavalheiro BG, Kulcsar MA, Hoff A d O, Brandão LG, Cernea CR, et al. Deaths related to differentiated thyroid cancer: a rare but real event. Arch Endocrinol Metab. 2017;61:222-7. https://doi.org/10.1590/23593997000000261.

42. Lamartina L, Grani G, Durante C, Borget I, Filetti S, Schlumberger M. Followup of differentiated thyroid cancer - what should (and what should not) be done. Nat Rev Endocrinol. 2018;14:538-51. https://doi.org/10.1038/s41574018-0068-3.

43. Metter D, Phillips WT, Walker RC, Blumhardt R. To use or not to use 1311 in thyroid cancer. Clin Nucl Med. 2018;43:670-1.

44. Michael Tuttle R, Ahuja S, Avram AM, Bernet VJ, Bourguet P, Daniels GH, et al. Controversies, consensus, and collaboration in the use of 131 I therapy in differentiated thyroid Cancer: a joint statement from the American Thyroid Association, the European Association of Nuclear Medicine, the Society of Nuclear Medicine and Molecular . 2019.

\section{Publisher's Note}

Springer Nature remains neutral with regard to jurisdictional claims in published maps and institutional affiliations.

Ready to submit your research? Choose BMC and benefit from:

- fast, convenient online submission

- thorough peer review by experienced researchers in your field

- rapid publication on acceptance

- support for research data, including large and complex data types

- gold Open Access which fosters wider collaboration and increased citations

- maximum visibility for your research: over $100 \mathrm{M}$ website views per year

At BMC, research is always in progress.

Learn more biomedcentral.com/submissions 